\title{
RECONCEIVING MUSIC AND MUSIC EDUCATION AS ETHICAL PRACTICES ${ }^{1}$
}

\author{
Reconceber a música e a educação musical \\ como práticas éticas ${ }^{2}$
}

\author{
Reconcebir la música y la educación musical \\ como prácticas éticas ${ }^{3}$
}

\author{
WAYNE BOWMAN \\ Brandon University \\ bowmanwd@gmail.com
}

\begin{abstract}
Conventional accounts of music as a source of "aesthetic experience" and of music education as "aesthetic education" have led the music education profession to seriously neglect the important links between music-making, the creation of community, and the development of character. In this talk I will argue that music education's understandings of music and of education are urgently in need of repair, and that a crucial part of that project involves recovery of their nature as fundamentally ethical and ethically-guided practices. Drawing on neo-Aristotelean accounts of the nature of practices, I will show how such understandings offer to enrich and vivify both our understandings of music-making and music teaching. I will argue that music-making should be regarded as a rich resource through which students explore the fundamental question What kind of person is it good to be? I will also argue that this question lies at the heart of professional practice for music educators. These ethical orientations alter profoundly what we conceive musicking and educating to be, the reasons they are important, and how we should go about engaging in them. They offer to shift our attention from teaching and learning about or in music to learning through music.
\end{abstract}

Keywords: Music-making and music teaching. Ethical practices. Learning through music.

Resumo: Narrativas convencionais da música como uma fonte de "experiência estética" e da educação musical como "educação estética" levaram a educação musical como profissão a negligenciar seriamente os importantes vínculos entre o fazer musical, a criação de comunidade e o desenvolvimento do caráter. Nesta fala ${ }^{4}$ argumentarei que concepções da área de educação musical acerca da música e da educação necessitam urgentemente ser revisadas e que uma parte crucial desse projeto envolve restabelecer a natureza da música e da educação como práticas fundamentalmente éticas e eticamente orientadas. Tomando como base perspectivas neoaristotélicas sobre a natureza das práticas, mostrarei como tais entendimentos enriquecem e vivificam nossos entendimentos do fazer musical e do ensino de música. Argumentarei que o fazer musical deve ser considerado um rico recurso para que os(as) estudantes explorem a questão fundamental: que tipo de pessoa é bom ser? Também argumentarei que essa questão está no cerne da prática profissional dos(as) educadores(as) musicais. Essas orientações éticas alteram profundamente o que concebemos que seja musicar e educar, as razões pelas quais essas práticas são importantes e como devemos proceder para nelas nos engajarmos. Essas orientações éticas propõem uma mudança da nossa atenção, do ensino e da aprendizagem sobre música ou em música para a aprendizagem por meio da música.

Palavras-chave: Fazer musical e ensino de música. Práticas éticas. Aprendizagem por meio da música.

1 In a sense, the phrase "ethical practice" is redundant - since, as I will argue in this talk, what distinguishes practices is their fundamentally ethical nature.

2 Em certo sentido, a expressão "prática ética" é redundante, uma vez que, como argumentarei nesta fala, o que distingue as práticas é sua natureza fundamentalmente ética.

3 En cierto sentido, la frase "práctica ética" es redundante, ya que, como argumentaré en esta charla, lo que distingue a las prácticas es su naturaleza fundamentalmente ética.

$4 \mathrm{O}$ autor se refere à conferência proferida no XXII Congresso Nacional da Abem, realizado em Natal (RN), de 5 a 9 de outubro de 2015. (Nota da Editora) 


\begin{abstract}
Resumen: Las descripciones convencionales de la música como fuente de "experiencia estética" y de la educación musical como "educación estética" han llevado a la profesión de la educación musical a descuidar seriamente los importantes vínculos entre el hacer musical, la creación de comunidad y el desarrollo del carácter. En esta charla ${ }^{5}$ argumentaré que comprensiones de la educación musical sobre la música y de la educación necesitan urgentemente una reparación, y que una parte crucial de ese proyecto implica la recuperación de su naturaleza como prácticas fundamentalmente éticas y guiadas por la ética. Basándome en los relatos neo-aristotélicos de la naturaleza de las prácticas, mostraré cómo tales comprensiones ofrecen enriquecer y vivificar tanto nuestra comprensión del hacer musical como de la enseñanza musical. Argumentaré que el hacer musical debe considerarse como un recurso valioso a través del cual los estudiantes exploran la pregunta fundamental: ¿Qué tipo de persona es bueno ser? También argumentaré que esta pregunta se encuentra en el corazón de la práctica profesional de los educadores musicales. Estas orientaciones éticas alteran profundamente lo que concebimos que es la música y la educación, las razones por las que son importantes y cómo debemos involucrarnos en ellas. Proponen cambiar nuestra atención, de la enseñanza y el aprendizaje sobre música o en la música al aprendizaje a través de la música.
\end{abstract}

Palabras clave: Hacer musical y enseñanza musical. Prácticas éticas. Aprender a través de la música.

I hope you will find this talk a provocative and challenging one. Indeed, I will be a little disappointed if you do not find it so. At the same time, though, I don't want it to be so provocative or challenging that you simply tune me out. I want to invite you, then, to set aside your personal convictions for the next hour or so as I try to engage you in conversation about what I believe are some terribly important concerns for music educators and music education concerns we often overlook in our haste to get on with our important jobs as teachers of music.

Music education is generally equated with the act of teaching music. On one level, that's quite reasonable, of course: music educators do teach music. But this really doesn't tell us much. In fact, music teaching and music education can be and often are very different processes. Not all music teaching leads to educational ends: not all music teaching is educational, either in intent or in result. Music can be and often is taught in ways that actually compromise or undermine educational outcomes. The notion that music teaching and music education are one and the same involves some rather dubious and misleading assumptions. Among these flawed assumptions is an unfortunate belief that the sole reasons for teaching music are to develop high levels of musical proficiency and to transmit particular kinds of musical knowledge. Let's call this the conservatory model for short. Its most grievous mistake, I think, lies in mistaking training for education. Alternatively, the approach known as "aesthetic education" would have us believe that music consists of "aesthetic objects" or "works," created by the musically gifted for consumption by (or for the contemplative gratification of) appreciative audiences. It most basic flaw lies in its focus on supposedly proper modes of musical reception and response. In both the conservatory and aesthetic education models, however, effective teaching is presumed to consist in the efficient transmission from teacher to student of the skills and knowledge each approach deems appropriate. (Freire, as you know well, has called this the "banking" model.)

\footnotetext{
5 El autor se refiere a la conferencia impartida en el XXII Congresso Nacional da Abem, realizado en Natal (RN), del 5 al 9 de octubre de 2015. (Nota del Editor)
} 
Both tend to assume, in other words, that the nature and value of music and the act of teaching it are relatively straightforward, technical processes. Both also tend to assume - again, I believe, quite wrongly - that the development and transmission of musical skills and knowledge invariably, inherently, and automatically have educational value. Both tend to overlook the troubling possibility that music teaching may lead to ends that are miseducative. We can teach music in ways that are neither musical nor educational. That is, I hope you will agree, a sobering prospect.

Musicians who are products of conservatory-oriented systems often find these claims rather troubling and challenging because they have been taught that music is self-evidently and inherently good: music is "intrinsically valuable," goes the argument, so learning about it and developing skills in it are reasons enough for teaching it. Questions about its broader educational values are either treated as irrelevant or dismissed as "extramusical." On these views, the primary concern of music educators is to teach music efficiently, in ways that assure the orderly and systematic development of basic musical skills and knowledge. If we do a thorough job transmitting musical skills and knowledge, in other words, music's educational value will take care of itself. I disagree quite strongly: The idea that musical outcomes are automatically and invariably educational leads to all kinds of instructional mischief, and poses clear problems for a profession that wants to be known as music education.

On the other hand, those who would have us attend primarily or exclusively to educational outcomes (let us call them "educationists") may and often do neglect "the music" - the attainment of outcomes that are genuinely or distinctively musical in nature. That is, an uncompromising focus on the educational reasons for learning music - the numerous and diverse ways it may benefit students' lives - frequently underestimates the substantial musical accomplishments upon which such educational aims and claims must be based. This is clearly undesirable if we want to be considered music educators. On one hand, then, we have instruction that may be musical but not really educational; on the other hand, we have instruction that purports to be educational but is not very musical - that lacks the musical rigor typically pursued by actual musicians in actual musical practices. Neither music nor education by itself is sufficient, I submit, for an adequate understanding of music education. Nor is music education the mere application of technical teaching formulas and methods to musical skills and knowledge.

We desperately need richer accounts of music, of education, and of how the two of them interrelate. These accounts need to include a prominent place for the tensions that exist both within and between them. The proper balance between music and education is a complex, delicate, and precarious one. It is also, I want to stress, the kind of ever-moving target that does not lend itself at all well to standardized technical approaches.

To review: Neither "music" nor "education" nor their mere sum give us adequate understandings of music education. Neither music nor the act of teaching it is good in itself: both have potentials for good and bad. Positive educational outcomes do not follow automatically just because music has 
been efficiently taught. Music, education, and music education - all three - are much more complicated than this. The point I want to ask you to consider is that "music education" lies at the intersection between two divergent, diverse, and complex human practices whose aims do not always or automatically harmonize. Neither by itself provides adequate grounding for music education philosophy or teaching. However, the recognition that music and education are practices does offer a promising advance from the dubious "aesthetic" accounts and conservatory models that have guided (or perhaps I should say "misguided") Western music education philosophy for an embarrassingly long time. What I want to explore with you here today is the notion that music-making and music education are, conceived and undertaken as ethical practices, tremendously powerful resources for the formation of character. To do this, I will need to outline a very particular understanding of what "practices" are and how they differ fundamentally from mere activities guided by "techniques" or "methods." Such understandings are crucial, I believe, to an adequate grasp of "music education": to decisions about why we teach, what we teach, and to how we gauge our success as music educators.

I will have more to say about the nature of human practices and their ethical guidance systems shortly. But first, let's consider a few of the problems associated with our conventional understandings of music. Music is not the uniform, unified affair assumed by aesthetic philosophy or the conservatory model: it is far more plural and diverse than these accounts allow. There are very few claims we can make defensibly for music as a whole - for all music, everywhere, for all times. Music is not an "it," we might say, but a "them" - a tremendously broad and disparate range of human undertakings, often with relatively little in common. The notion of a singular, unified domain of "music," then, is a trouble-making abstraction that seeks to bring together under one label human actions that differ from each other, often in profound ways. In Christopher Small's memorable words, "There is no such thing as music." Music, in other words, is not static or uniform, nor is it a "thing" - it is not an entity or an object. It is, rather, a mode of human action, a tremendously diverse human practice. Most of our claims about "the" nature and value of music, then, are misleading - because music has no single "nature" and no single, invariant, or intrinsic "value" ("aesthetic" or otherwise). Musical practices are plural and diverse; and so are their natures and values. Moreover, because musical practices are fundamentally social, their natures and values are continually contested and changing - at least this is true of musical practices that are living, vital, and thriving. Crucial to an adequate understanding of music, then, is awareness of both its radical multiplicity and its fluidity. Students technically inducted into a single musical tradition do not develop this awareness, and accounts of music that do not acknowledge this multiplicity and fluidity are simply inadequate. Living musical practices do not consist of single, unchanging sets of conventions, meanings, or values.

We might say the same things about educational practice, by the way: what constitutes education (as distinct from schooling, or training, or indoctrination) is a necessarily open question, with answers that are plural, diverse, 
and often contested. As I've said, education does not occur simply because students have successfully navigated the hurdles placed before them in institutions devoted to teaching. Teaching may or may not be educational; and much of what passes for education in our teaching institutions is not. These are pretty outrageous claims, I admit, but I want to keep your attention. If you'll bear with me I will try to explain.

As I said earlier, music education lies at the intersection of two rich, complex practices: music and education. The institutions that have evolved in support of music education, however, seldom succeed in illuminating the complexity of these intersections or the interactive tensions they inevitably entail. Adding "instructional methods" (how-to-teach formulas) to musical skills (howto-make-"music" formulas) does not yield musical education. Music education does not consist in the mere sum of proficiency in a single musical practice and knowledge about "the best way to teach." What most concerns me about such misguided beliefs is their reduction of musical and education and music education to technical affairs where the predominant concerns are efficiency, control, and standardization. I believe that both music and education are deeply ethical endeavors whose meanings and values are being eclipsed increasingly by technical knowledge. And that concerns me because I believe that practices (musical, educational, and other) are extraordinarily valuable ethical resources - modes of action through which we learn crucial and durable lessons about what it means to live in ways that are ethically responsive and responsible. The replacement of ethical knowledge with technical knowledge is deeply troubling because ethical discernment is among the most important benefits music and education confer. I believe that our primary concern as music educators should be the development of musicians as people: the kind of character they develop in and through musical engagement. We need to construe music education, I submit, as a fundamentally ethical enterprise, focused primarily upon (a) what kind of person it is good to become, (b) the kind of world we require to thrive as human beings, (c) what kinds of musical and instructional engagements support and sustain concerns like these, and (d) how. And again, the distinction I am concerned to point out is one between music and education as practices (which take their guidance from fundamentally ethical considerations) and mere activities, techniques, or methods whose success is measured by the efficiency with which they attain neatly specified, standardized outcomes. Because music is not a uniform, static entity with intrinsic value, and because teaching music can serve ends both educational and miseducational, ethical deliberation is a crucial obligation for music educators. It is, in fact, what distinguishes responsible professional action from mere activity.

\section{PRACTICES, ETHICS, AND INTERNAL “GOODS": THE THREAT OF TECHNICAL RATIONALITY}

Because I am urging that we regard processes like music-making and education first and foremost as practices - as processes involving and sustained by human action - I owe you a definition. A practice (as I am using 
the term here) is a socially rooted, complex, coherent, and cooperative activity that grows over time into its own ethical world. Each part of this definition is crucial if we are to distinguish practices from mere activities, from mere technical endeavours, from jobs, and from habitual or institutionalized patterns of behaviour. Three aspects of this definition ${ }^{6}$ are especially important: (1) Practices are social phenomena; (2) practices emerge from and are sustained by negotiated, cooperative engagements between and among people; and (3) practices grow over time into distinctly ethical worlds. To these I hasten to add a fourth consideration: Because they are social, cooperative and ethical (rather than technical), (4) practices are changeable and changing: they are what I have called moving targets; they are always in the process of becoming something other than they have been.

The philosopher John Dewey claimed that the primary importance of arts stems from their capacity to cure us of the "prejudice" that objects have fixed, inalterable value. Why should we need to be "cured" of this idea? How exactly is it "prejudicial"? The short answer is that practices and the values they embody are human constructs - not fixed or inalterable things - and in order to thrive in the ever-changing human world we need habits that are pliable, flexible, attuned and responsive to changing circumstances. This pragmatic view is grounded in the belief that action, not consciousness or representations of a "thing" called "reality," is the foundation of human life. Action - what we do intentionally - is foundational, not thought, not abstraction, and not the "objects" to which these processes typically give rise. Human life is more like riding on a rapidly moving train, then, than sitting perched atop a mountain somewhere. From pragmatist perspective, the human world is always moving and changing. And in a changing world, as Dewey rightly warns us, rigidity can be a dangerous thing. Among the most valuable habits we can develop (and this has important implications for our understandings both of education and music, I believe) is the habit of changing habits when and if change becomes necessary.

Now, clearly, what I am suggesting is that human practices are where we develop and nurture capacities like this; and further, that music and education have special potentials in this regard. However, our prevailing approaches

\footnotetext{
6 An important caveat: This is a very abbreviated definition, offered because of its relative ease of accessibility. Here is Alasdair Maclntyre's (1984, p. 187) definition of practice: "Any coherent and complex form of socially established cooperative human activity through which goods internal to that form of activity are realised in the course of trying to achieve those standards of excellence which are appropriate to, and partially definitive of that form of activity, with the result that human powers to achieve excellence, and human conceptions to the ends and goods involved, are systematically extended." Joseph Dunne $(2005$, p. 368) puts it this way: "A practice [...] is a coherent, complex set of activities that has evolved cooperatively and cumulatively over time, that is alive in the community who are its practitioners, and that remains alive only so long as they remain committed to sustaining - and creatively developing and extending - its internal goods and its proper standards of excellence (this commitment constituting them as a community)." Let me stress what I hope is obvious from these definitions: this understanding of "practice" is not to be confused with habitual repetition, the development of automaticity: practices are not just things people do. A practice is much more closely aligned, because of the centrality of ethical discernment, to the pragmatist habit of changing habits in light of changing demands of one's situation.
} 
to music education diverge rather significantly from this account of practices. Instead of preparing us for what may be or what is about to be, they are designed to prepare us for what is or what has been. Our methods and institutions are designed to orient and prepare learners for the status quo rather than how to thrive amidst unpredictability or change. Music teaching more often embraces past practice than musical futures. It seeks to transmit what "is," or what once was, rather than preparing students to contribute meaningfully to musical practices that are in the process of emerging or that may be yet to emerge.

I hope it is becoming clearer why I have stressed the ethical nature of practices. Because practices are dynamic, the habit of changing habits must be a central concern. I hope it is also clear that despite what I said in my opening remarks, musical practices may well be educationally important ethical resources. But these are educational potentials, not guarantees. Engaging in a practice may benefit practitioners in two different ways. Healthy practices involve two kinds of "good": internal goods and external goods. A practice's internal goods are the human ends it exists most fundamentally to serve, the benefits without which it cannot continue to exist as a practice. Internal goods are the beating heart or the nerve of a practice, the benefits that define and distinguish it from others: benefits that can only be obtained by engaging faithfully, authentically, or ethically in the practice at hand. And importantly, excellence in achieving a practice's internal goods benefits everyone involved in the practice.

A practice's external goods, on the other hand, include things like financial security, power, prestige, praise, and so on - things that are not the precisely the point of the practice yet undeniably serve to support and sustain it. External goods benefit practitioners differentially: people compete for them; there are winners and losers, and benefits accrue to winners as individuals (or institutions) rather than to the practice as a whole.

While both are "goods" and while healthy practices require both, a practice's internal goods may be undermined or threatened by its many external goods. So it is very important to be clear which are which and how they differ. Because practices are social, cooperative, and complex, these are not questions with simple or easy answers. And that is why practices are fundamentally ethical: At their core lie difficult questions about what kinds of action authentically and faithfully sustain their internal goods, what kinds of action undermine them, and whether the institutions put in place to protect the practice's internal goods are actually continuing to do so.

Put differently, while external goods are important, (it is hardly unreasonable for a musician or a teacher to expect to be paid for her work, for instance), practices cannot remain viable and sustainable as practices unless their internal goods are protected and nurtured. The goods internal to a given practice are benefits that can be attained only through that particular practice. A practice's internal goods benefit and sustain practitioners' involvement by providing them with experiences they can drape their lives around - things that become prominent aspects of their identities or character. Internal goods 
sustain a practice in no small part because they enable its practitioners to thrive. They are linked in important ways to the ways practitioners live their lives - to the kind of people the practice uniquely enables them to become. There is no competition for a practice's internal goods: they are available to all who engage properly, faithfully, authentically in the practice at hand.

And yet - and this is a crucial point - the precise nature of a practice's internal goods is always and necessarily open to question. The nerve of a practice (the fundamental purpose for which it exists) is not something preordained or set in stone, but an ongoing ethical concern in whose definition and protection each and every genuine practitioner has a stake. Because practices are social and cooperative, we might say - a matter of negotiated consensus among conscientious practitioners - the appropriate balance between their internal and external goods is open to question and often the focus of vigorous debate. The ethical questions What kind of person is it good to be? and What actions are essential to the faithful execution of this practice? do not have single, definitive, unchanging answers.

Now, where practices are widely valued, people create institutions to preserve and protect them. However, these very institutions may come to compete with or undermine a practice's internal goods, threatening its viability and sustainability as a practice. In other words, the external goods and institutions associated with a practice - the "methodologies," for instance, that offer to replace ethical deliberation with techniques, prescriptions, and recipes - may over time become rigid and incompatible with the ethical (ever evolving) "nerve" that guides and sustains the practice. It is imperative, then, that we not equate practices with the institutions (schools of music, conservatories, methodologies like Orff or Kodaly, and economic benefits, for instance) created to serve and protect them.

I hope the point of these claims is becoming clearer. I am urging that we conceive of music-making and musical education as practices - as socially rooted, complex, coherent, and cooperative activities that constitute distinctive "ethical worlds" - worlds whose continued health and vitality requires that they be continually questioned, revised, extended, reconstructed. And I am urging that recognizing music and education as living human practices - diverse, ever-evolving, ethically guided - makes immense differences in how we think about music education but, more importantly, how we do it, how we prepare future generations to do it, and how we gauge the success of these actions.

What distinguishes practices from mere activities, techniques, and institutions is their relentless, ethically guided pursuit of the goods deemed internal to the practice. Ethical vigilance is crucial. And because such vigilance is inescapable - since it is central to practical engagement that is authentic - true practices are where we learn most vividly and indelibly what kind of person it's good to be. I hope you can see this is a tremendously potent claim for music-making, one that takes us well beyond the realm of technical realm of training.

And yet technical training appears to be what music educators are most comfortable providing. Our overwhelming concern seems to be to teach music 
methodically and efficiently - in ways that lend themselves to quantification and supposedly objective measurement. We teach people how to teach, for instance, but not about the ways teaching may fall short of aims and goals that are actually educational. We have become very good at training teachers and teaching them to develop certain of their students' musical skills, but we seldom ask if the outcomes of such instructional programs are truly educational, or in what sense.

We seem determined, in other words, to technicise musical and educational practices: to make them over in ways that enable us to exercise maximal control over their key operations by "methods" whose successful implementation can be taught, monitored, and measured unambiguously. The ideal to which such technical rationality aspires, however, is practitioner-proof activity.

The success of education is not gauged by technical efficiency - "how-to" - but by ethical fluency - "whether-to," "when-to," "to-what-extent-to." We assess the success of education not so much by the specific tasks it prepares us to perform but by the kind of people it enables us to become (and collectively, by the kind of society it helps us create and sustain). If education involves pursuit of answers to the ever-open ethical question What kind of person is it good to be? it is imperative that music educators ask How do music and music-making put me (or us) in touch with these questions? What kinds of answers do our current musical and instructional habits tend to favor?

Of course, one of the reassuring things about training is that it gives students lots to learn and gives teachers lots to teach. Training can keep us very, very busy. But is it the right kind of busy-ness? Does training deliver enough? Does it accomplish the right things, the things we will most need to thrive as human beings and as a society in tomorrow's world? Training is preoccupied with eliminating perceived obstacles and avoiding failure - these being impediments rather than assets. Training is obsessed with things like standards and standardization: with "what works" - not unlike the processes McDonalds uses to turn out near-identical fast food "meals" world-wide. Is music education's fondness for instructional techniques the McDonaldization of music education? Where in the teaching/learning process do prospective music teachers or their students learn to ask crucial ethical questions like Why? or To what ends? or What kind of people are we trying to become? and How does this instructional or musical practice promise to get us there?

However important musical training may be (and make no mistake, it is both useful and important), it invariably falls short of musical education. Music education is a considerably thicker soup. It is concerned with things like creativity, adaptation, responsibility, and rightness of action. Problems and questions are among its most precious assets. The habits education seeks to nurture are not just those devoted to preserving past or present practice, but with extending, modifying, or transforming them. Education accepts risk, nurtures responsibility and initiative, and seeks to create practitioners who can not only participate meaningfully in the practice at hand but can also challenge and even change it if and when that is appropriate. 
I am deeply concerned at what I see as a tendency in music education to replace practices and the ethical problems they entail with technical activity in which good results are assumed to follow automatically from acts of teaching and music-making, and in which standardization, predictability, and control are higher priorities than creative exploration and vigorous debate. If music-making and teaching are practices, their value is always contingent, always potentially problematic, and ever subject to reassessment and revision. The point of music education, then, is not to reveal timeless truths or to develop fail-proof skills, but to facilitate the habit of changing our action habits and to help us see when such change may be required. As such, it should sometimes provoke. It should challenge things we take for granted, actions undertaken without carefully considering the desirability of their consequences.

\section{ETHICAL DOES NOT MEAN MORAL}

I've gone to considerable lengths to distinguish practical from the technical rationality - to differentiate the ethical nature of practical know-how from the technical predilections broadly embraced by contemporary music education. But this leaves unaddressed another point of potential confusion that must be addressed before I bring this talk to a close, that being the difference between ethical and moral considerations. As I hope you will have gathered, what I have been proposing here is not a moral claim for music or music education.

We could easily devote many hours to this topic, but I can only sketch its basic details here. The main point, as I have just said, is that morality and ethics are not synonymous: morality is, rather, a particular "subset" of ethical thought. Morality, in contrast to ethics, revolves around obligations: it is concerned with what it is right to do in situations where right and wrong courses of action can be rendered relatively clear and unequivocal. Morality seeks to identify rule-guided obligations rather than, as I have been trying to urge here, the nature of the good life (what kind of person it is good to be). Ethics is first person and practical, concerned with open questions like Who do I want to be? How should I live my life? and What kind of society is necessary if I'm to make good on my answers to questions like these? Morality, on the other hand, asks questions like What is it right to do? How must I act?

These may sound like subtle distinctions, especially given the brevity with which I've had to introduce them here, but they are, I believe, very important ones. Those who equate ethics and morality mistakenly assume that without morality's special, logically-derived obligations human action is guided by nothing but subjective inclinations. From a moralist perspective, there is only one alternative to acting in accord with rationally derived and delineated, rule-based obligations: conduct that is selfish and self-serving. To act ethically, on this view, is simply to act in accord with one's moral obligations, setting aside self-interest. People who act out of self-interest are irresponsible, perhaps even immoral. People who fail to adhere to their moral obligations are bad people. 
On the view I am advancing here, however, this rules-versus-inclinations, good-people-versus-bad-people model neglects a number of very important things. Most significantly, it wrongly assumes that without obligations personal dispositions to act one way rather than another are nothing but arbitrary, self-serving, manifestations of self-serving desire. Virtue ethics - the perspective upon which I prefer to draw ${ }^{7}$ - vigorously contests this assumption. There are important alternatives to rules, obligations, and rigid codes of conduct: alternatives that are much more useful in circumstances characterized by change and ambiguity; alternatives that are far more supple, flexible, and better suited to thriving in a changing world; alternatives that do not require correction or guidance by obligation. In the rough-and-tumble of everyday human life, character is often a more useful and reliable asset than the abstract rules and reasons from which morals take their guidance. And character lies at the heart of the open question I have posed repeatedly here: What kind of person is it good to be?

In other words, ethical decisions are often more reliably guided by the kind of person one has become than by morality's rules and obligations. Not all ethical decisions involve choices between good and bad: more often, they involve choices among competing goods. Under such circumstances - in a changing and ambiguous world, in other words - ethical choices need to be guided by something more responsive and supple than obligations: by one's character. The rigidity and generality of morals,${ }^{8}$ their formulaic and prescriptive nature, makes them ill-suited to ethical situations in which action options cannot be reduced to binary yes/no or right/wrong choices, situations in which right action cannot be determined by recourse to logic-driven deliberations or abstract codes of conduct. There is far more to ethics than moral rectitude, in other words, and that "more" involves matters of vital human import. Accordingly, my claim that music and education should be construed as fundamentally ethical does not amount to a claim that they make people "moral." Indeed, there is abundant evidence this is not the case.

With all this said, I now return to my main point: that music-making (approached, I trust you can see, in a very particular way) involves ethical habits and dispositions, and not just tangentially but centrally. And these make music a vital resource for exploration and development of the capacity for ethical discernment: a profoundly educational resource.

\footnotetext{
7 This in contrast to the better known ethical orientations known as deontology and consequentialism.

8 I might as easily have said "their rigidity and their specificity." Since this sounds contradictory, let me attempt an explanation. To criticize morals for their specificity is to single out their inability to travel well, their inflexibility - their categorical nature. In choosing "generality" instead, I am criticizing their presumption to be broadly explanatory and universally applicable - and their incapacity to address the particularity or uniqueness of individual circumstances. Either word is likely to invite misunderstanding, but my hope is that "generality" will be less prone to misinterpretation since one of the distinctive characteristics of phronesis its sensitivity to particularity (its disinclination to bring things under existing categories).
} 


\section{PRACTICES AS ETHICAL RESOURCES: EDUCATING THROUGH MUSIC}

Are these distinctions that don't make a difference, theoretical lines of thought without implications for the ways we understand and undertake music making or teaching? Obviously, I do not think so. If what I have been saying is valid, then questions about music's value or goodness extend well beyond whether it sounds good, whether it is well-executed, or even whether it is authentic to the practice at hand. Music making is not its own end, but is always also a means to other ends. The point of musical instruction within the context of education is not just training "in" music but educating "through" music: the development of habits, attitudes, dispositions, and capacities that enable people to live their lives more fully than would otherwise be possible. This makes of music education something far more momentous than the refinement of technical skills and aesthetic sensitivity.

We become, through the practices in which we immerse ourselves, people for whom seemingly little differences make a great deal of difference. We develop care about what we are doing, and how, and with whom, and for whom, and why, at the same time we develop significantly richer understandings of what it is we as practitioners are really doing and why. Practitioners develop deep attachments to life and living through their ethically guided practices, and those attachments become important parts of who they are - of their identity and character.

As we have seen, the nature of human practices is that they are ever under construction and ever-changing: the nerve of a practice is never something, then, that is "just there" waiting for practitioners to sign on. Entry into a practice - musical or educational - involves apprenticeship in which one engages in successive approximations aimed at something that can never be explicitly or exhaustively stipulated because practices are alive, ever-under-collaborative-construction, ever-evolving. Being a practitioner (one whose actions are true to the internal goods of the practice at hand) involves actions that are ever open to question. Such questions, the objects of debate widely distributed among members, are vital parts of what keeps practices vital. Disagreements, questions, and debates are crucial parts of the engines that keep human practices humming along. ${ }^{9}$

As modes of human action, practices are always in the process of becoming something other than they have been. At the same time, practices always have histories and traditions to which practitioners owe their allegiance. Finding one's way between the unacceptable extremes of radical novelty and blind adherence to tradition (between abject freedom and coercive constraint) is a fundamental part of the ethical challenge every practitioner faces. These commitments also become fundamental parts of who a successful practitioner is:

\footnotetext{
9 As Alasdair Maclntyre (1984, p. 222) writes, "Traditions, when vital, embody continuities of conflict [...]." Moreover, he suggests we consider living traditions as "historically extended, socially embodied argument[s] [...] [that are] precisely in part about the goods which constitute that tradition."
} 
her identity or character centrally involves her ability to engage effectively in a collective mode of action for which there is no definitive book of rules.

Each practice has its own set of internal goods, its own vision of what kind of person it is good to be, its own vision of virtuous conduct or human thriving. And as modes of collective, cooperative action, every practice entails its own ways of being and of becoming. As Christopher Small taught us, How we music is who we are.

Why music and music-making rather than some other practice? Or why jazz rather than hip hop or country or samba or art music? Why presentational music-making rather than participatory music-making? Why live, face-to-face music-making rather than computer generated music? These are complex questions with answers that are no less complex. However, this complexity this intricacy - is precisely what makes practices important ethical resources: the questions I have posed above are ethical questions after all, questions concerned not just with what to do, but with kind of person it is good to be. And one of the things I have tried to stress about ethical questions is that, unlike moral questions, they do not have prescriptive or definitive answers. The answers they demand are personal and provisional. That, too, is part of the distinctive nature of ethics. And if we fail to teach music in ways that help our students explore these questions in these ways, we neglect some of its more important educational potentials. Practices are tremendously important ethical resources. They are where we develop commitment to particular ways of being and doing, where we develop values that define who we are, who we hope to become, and how best to live our lives.

Again, Why musical practices rather than some other? And Why this musical practice rather than that one? These are fundamental questions to which we music educators devote scant attention. We find it easier to mount advocacy campaigns for what we are already doing than to ask whether it is right, how it might be made better, or whether other musical doings might serve educational or ethical ends more effectively. We find it easier to urge support for our existing habits than to examine whether they serve the ends we intend. In so doing, we reduce educational and musical practices to mere technical pursuits; and among the many things lost along the way are their ethical nature, their contributions to developing personal character, the vivid and distinctive visions they offer us of human thriving.

Not all practices are equally momentous in ethical potency, or in terms of their capacity to engage the ethical imagination. Surely among music's advantages in this regard is its bodily basis, its capacity to engage both an embodied mind and a minded body. Music has unparalleled capacity to engage imagination and feeling; to integrate mind and body; to infuse personal agency with a sense of belonging; and to bring these powerful resources to bear on the all-important ethical question, What kind of person (and society) is it good to become? Music-making is an example par excellence of human flourishing: or at least, taught and practiced in certain ways, it may be so.

However, infatuated with efficiency and technical rationality, music educators seem increasingly determined to embrace training rather than edu- 
cation, easy answers rather than better questions. Our understandings of music, of education, and of music education are in urgent need of repair. A crucial part of that project is recovery of their nature as ethical and ethically-guided practices - as rich resources for exploring crucial questions about what kind of people music education should enable us to become.

How would it change our instructional habits and our curricula if music education were to embrace things like problems and ambiguity? If we were to teach on what R. Murray Schafer calls "the verge of peril"? If we were to conceive of music and teaching as fundamentally ethical endeavors - as precious resources for exploring questions like What kind of person is it good to be? and What kind of society do we want our children's children to live in? How might music uniquely lend itself to exploring issues like these? What might it really mean to be musically educated in the 21 st century? Although that is a talk for another time, here is how I would begin to respond. It would probably involve (1) emphasis upon creativity and participatory (as distinct from presentational) performance, not just reinterpretations of pieces created by others; (2) a shift away from ethnocentric exclusivity in favor of rich engagements in multiple musical practices that are truly diverse; and (3) commitment to developing civic responsibility and artistic citizenship, concerns that depart dramatically from the tired, misleading notion of teaching music "alone."

I will draw these remarks to a close with a few ideas that I hope you will take with you and continue to think about. Music education, in contrast to mere training, is preparation for citizenship, and not in a trivial sense: it implicates fundamentally ethical concerns about what kind of people we wish to be, what kinds of societies we want to live in, and how our musical actions help us answer such questions. The musically educated are prepared not just to fit into or replicate existing practices but to transform, extend, and even change them where needed. These considerations place profound ethical questions at the heart of music education deserving of that name. If, as I have argued, music and education are human practices (defined, that is, as I have sought to define them here), then professional actions that are not ethically oriented and ethically guided are not educational. And if our musical undertakings neglect the ethical, they are not fully musical. Ethics are not optional add-ons to musical and music educational practice: they are essential features of professional praxis.

\section{REFERENCES}

DUNNE, Joseph. An intricate fabric: understanding the rationality of practice. Pedagogy, Culture and Society, [s. l.], v. 13, n. 3, p. 367-390, 2005.

MacINTYRE, Alasdair. After virtue: a study in moral theory. Notre Dame: University of Notre Dame Press, 1984. 
Dr. Wayne Bowman, recently retired as a professor of music and music education, has taught at Brandon University (Manitoba, Canada), Mars Hill University (North Carolina, USA), New York University, and the University of Toronto. In addition to numerous book chapters and journal articles, he has published three books: Philosophical perspectives on music (1998), The Oxford handbook of philosophy in music education (2012, in collaboration with Dr. Ana Lucia Frega), and Artistic citizenship: artistry, social responsibility, and ethical praxis (2016, with David Elliott and Marissa Silverman). He helped found the scholarly journal Action, Criticism, and Theory for Music Education, and served as its editor for ten years. Dr. Bowman is also a trombonist with extensive interests in jazz and jazz education. 